Note

\title{
Effect of Octreotide Treatment on Graves' Ophthalmopathy
}

\author{
Ali riza UYSAl, Demet ÇORAPÇIOǦLU, Vedia Cesur tonyUKUK, Sevim GÜllü, Hasan SAV, \\ NURi KAMEL AND GƯRBƯz ERDOĞAN
}

\author{
Department of Endocrinology and Metabolic Diseases, Ankara University School of Medicine, Ankara, Turkey
}

\begin{abstract}
In this study, nine patients with Graves' ophthalmopathy with positive clinical activity score (CAS), who were either unresponsive or not suitable for glucocorticoid treatment, were given $100 \mu \mathrm{g}$ of octreotide three times daily, subcutaneously, for three months. The mean age was $49 \pm 13$ years. All patients were under either propylthiouracil or methimazole therapy and were euthyroid for at least one month prior to the start of the octreotide treatment. The mean degree of proptosis as measured with the Hertel exophthalmometer decreased slightly after the treatment (22.0 \pm 3.0 vs $19.6 \pm 2.4$ for the right eye and $22.2 \pm 1.9$ vs $20.2 \pm 2.2$ for the left eye; $p<0.05)$. The mean activity score decreased from $3.2 \pm 0.8$ to $1.7 \pm 1.1(\mathrm{p}<0.005)$ and the mean score of eye signs according to the NOSPECS classification showed improvement with octreotide therapy $(3.2 \pm 0.7$ vs. $2.2 \pm 1.4 ; p<0.05)$. Seven patients responded favorably to octreotide treatment. In the remaining two no improvement was observed. Four of the responders could be followed up for 20 months after the treatment and all maintained the favorable state of eye findings obtained with octreotide. We conclude that octreotide seems to be a safe and effective drug in Graves' ophthalmopathy, especially in improving soft tissue involvement, and can be used in patients who are unresponsive to glucocorticoid treatment or who cannot use these drugs for some reason.
\end{abstract}

Key words: Graves' ophthalmopathy, Octreotide

(Endocrine Journal 46: 573-577, 1999)

GRAVES' ophthalmopathy (GO) is an autoimmune disease that affects orbital tissue and in its severe forms may compromise vision. Different treatment methods, such as immunosuppressive treatment, orbital irradiation and decompression (surgery), have been used for the treatment of moderate to severe GO [1-3]. These existing treatments are not fully satisfactory and have several major and/or minor side effects. Octreotide (OCT), a potent somatostatin analogue which has been used for the treatment of several diseases, has recently been proposed as an effective drug in the treatment of GO in some studies [1-5], but there is doubt about its value since it was found to be not beneficial in one study [6].

Received: July 13, 1998

Accepted: February 19, 1999

Correspondence to: Dr. Demet ÇORAPÇIOĞLU, İbn-i Sina Hastanesi, Endokrinoloji ve Metabolizma Hastalıkları Bilim Dalı, 10. Kat D- Blok, 06100 Samanpazarı, Ankara, Turkey
The purpose of this study is to assess the efficacy of OCT on the disease activity, estimated by clinical activity scoring (CAS), in patients with moderately severe GO who cannot tolerate or are unresponsive to corticosteroid (CS) therapy.

\section{Patients and Methods}

\section{Patients}

Nine patients ( 4 males, 5 females, mean age $49 \pm 13$ years) with active GO were included in the study. The duration of Graves' ophthalmopathy was 3-36 months (mean 14.2 \pm 11.3 ) and none was a smoker. All the patients were euthyroid for at least one month on antithyroid drugs (propylthiouracil or methimazole) before the start of the study. Three patients had received radioiodine therapy for hyperthyroidism two years before. Five patients had received $1-1.5 \mathrm{mg} / \mathrm{kg} /$ day corticosteroid (CS) ther- 
apy for approximately six months for GO previously but no improvement occurred and had been off CS for at least three months (mean $4.33 \pm 1.53$ months) prior to the study. The remaining four patients were not appropriate candidates for CS therapy since they had either active gastritis or peptic ulcers on endoscopy. One patient had had an eye muscle operation for strabismus.

\section{Methods}

Octreotide acetate (OCT) (Sandostatin, Sandoz Pharma Ltd) $100 \mu \mathrm{g}$, subcutaneously, three times a day, was given to the patients. The total study period was three months. The euthyroid state was maintained and the patients received no other treatment for GO during the study. The study was approved by the local Ethical Committee and informed consent was obtained from all the patients.

\section{Assessment of Efficacy}

Eye Scoring: All patients were evaluated by the same physician (D.Ç.) once every two weeks during the study. Proptosis was measured with a Hertel exophthalmometer. Limits for proptosis were adjusted for the local population [7]. NOSPECS classification was recorded as, Class 0 , No physical signs or symptoms; Class I, Only signs, no symptoms; Class II, Soft tissue involvement; Class III, proptosis; Class IV, extraocular muscle involvement; Class $\mathrm{V}$, corneal involvement; Class VI, optic nerve involvement. Disease activity was assessed by assigning 1 point for the presence of each of the following signs and symptoms: spontaneous retrobulbar pain, pain on eye movement, eyelid erythema, conjunctival injection, chemosis, swelling of the caruncle and eyelid edema or fullness and the sum of these points was the clinical activity score (CAS; range 0-7) [8]. Moderately severe ophthalmopathy was defined as being in one of the following NOSPECS categories: either Class II with severe soft tissue involvement or Class III or IV. Two millimeters or more decrease in the proptosis value and one or more point decrease in the activity score were accepted as improvement.

Orbital computerized tomography or magnetic resonance imaging (MRI) scans were carried out on patients before the treatment and all showed some degree of involvement in extraocular muscles which was determined by muscle size measurements.

Statistics: All statistical analyses were performed by Wilcoxon matched pairs' tests. For correlation analysis Kendall's tau-b test was used. A P values less than 0.05 was regarded as significant.

Table 1. Clinical characteristics of the patients before octreotide treatment.

\begin{tabular}{ccccccc}
\hline $\begin{array}{c}\text { Case } \\
\text { Number }\end{array}$ & $\begin{array}{c}\text { Age } \\
\text { (Year) }\end{array}$ & Sex & $\begin{array}{c}\text { Disease } \\
\text { Duration } \\
\text { (months) }\end{array}$ & $\begin{array}{c}\text { NOSPECS\# } \\
\text { Classification } \\
\text { (Class) }\end{array}$ & $\begin{array}{c}\text { Clinical } \\
\text { Activity Score* } \\
\text { (CAS) }\end{array}$ & $\begin{array}{c}\text { Prior Medical } \\
\text { Therapy }\end{array}$ \\
\hline 1 & 37 & F & 6 & III & 4 & CS \\
2 & 47 & M & 3 & II & 4 & (-) \\
3 & 50 & F & 24 & III & 2 & CS, RAI \\
4 & 49 & M & 10 & III & 4 & (-) \\
5 & 33 & F & 7 & III & 2 & (-) \\
6 & 63 & M & 12 & IV & 4 & CS, RAI \\
7 & 37 & M & 24 & III & 3 & CS \\
8 & 74 & F & 36 & IV & 3 & CS \\
9 & 52 & F & 6 & IV & 3 & Op.
\end{tabular}

CS: Corticosteroid, RAI: Radioiodine treatment, Op: Operation for strabismus, \#NOSPECS Classification: Class 0; No physical signs or symptoms, Class I; Only signs, no symptoms, Class II; Soft tissue involvement, Class III; Proptosis, Class IV; Extraocular muscle involvement, Class V; Corneal involvement, Class VI; Optic nerve involvement, ${ }^{*}$ CAS: Spontaneous retrobulbar pain, pain on eye movement, eyelid erythema, conjunctival injection, chemosis, swelling of the caruncle and eyelid edema or fullness; and the sum of these points was the clinical activity score (range 0-7). 


\section{Results}

Extraocular muscle involvement, evaluated as enlargement of the muscles, was observed in all patients either by CT or MRI: enlargements affecting the in- ferior, medial and superior rectus muscles in three cases (cases 6, 8,9) and enlargements affecting one or two rectus muscles in the remaining six.

The clinical characteristics of the patients are shown in Table 1 . The mean CAS decreased significantly from $3.2 \pm 0.8$ to $1.7 \pm 1.1$ after treat-

Table 2. Activity scores and proptosis measurements of patients before and after octreotide treatment.

\begin{tabular}{|c|c|c|c|c|c|c|}
\hline \multirow{2}{*}{$\begin{array}{l}\text { Patient } \\
\text { Number }\end{array}$} & \multicolumn{3}{|c|}{ Clinic Activity Score (CAS) } & \multicolumn{3}{|c|}{ Proptosis (mm) } \\
\hline & & Before & After & & Before & After \\
\hline \multirow[t]{5}{*}{1} & Eyelid edema & + & - & Right Eye & 22 & 20 \\
\hline & SRP & + & - & Left Eye & 21 & 19 \\
\hline & PEM & + & + & & & \\
\hline & Eyelid Erythema & + & + & & & \\
\hline & Score & 4 & 2 & & & \\
\hline \multirow[t]{5}{*}{2} & Eyelid Edema & + & - & Right Eye & 19 & 19 \\
\hline & SRP & + & + & Left Eye & 22 & 20 \\
\hline & Eyelid Erythema & + & - & & & \\
\hline & Caruncle Swelling & + & - & & & \\
\hline & Score & 4 & 1 & & & \\
\hline \multirow[t]{3}{*}{3} & Eyelid Edema & + & - & Right Eye & 26 & 25 \\
\hline & Caruncle Swelling & + & + & Left Eye & 24 & 24 \\
\hline & Score & 2 & 1 & & & \\
\hline \multirow[t]{5}{*}{4} & Eyelid Edema & + & - & Right Eye & 24 & 19 \\
\hline & Caruncle Swelling & + & - & Left Eye & 24 & 19 \\
\hline & SRP & + & + & & & \\
\hline & Eyelid Erythema & + & - & & & \\
\hline & Score & 4 & 1 & & & \\
\hline \multirow[t]{3}{*}{5} & Eyelid Edema & + & + & Right Eye & 23 & 21 \\
\hline & PEM & + & - & Left Eye & 24 & 22 \\
\hline & Score & 2 & 1 & & & \\
\hline \multirow[t]{5}{*}{6} & Eyelid Edema & + & + & Right Eye & 23 & 21 \\
\hline & SRP & + & + & Left Eye & 24 & 22 \\
\hline & PEM & + & + & & & \\
\hline & Conjunctival Injection & + & + & & & \\
\hline & Score & 4 & 4 & & & \\
\hline \multirow[t]{4}{*}{7} & Eyelid Edema & + & + & Right Eye & 24 & 19 \\
\hline & Eyelid Erythema & + & - & Left Eye & 22 & 19 \\
\hline & Conjunctival Injection & + & - & & & \\
\hline & Score & 3 & 1 & & & \\
\hline \multirow[t]{4}{*}{8} & Eyelid Edema & + & + & Right Eye & 16 & 16 \\
\hline & SRP & + & + & Left Eye & 19 & 19 \\
\hline & Eyelid Erythema & + & + & & & \\
\hline & Score & 3 & 3 & & & \\
\hline \multirow[t]{4}{*}{9} & Eyelid Edema & + & - & Right Eye & 21 & 17 \\
\hline & Eyelid Erythema & + & + & Left Eye & 20 & 17 \\
\hline & Conjunctival Injection & + & - & & & \\
\hline & Score & 3 & 1 & & & \\
\hline Mean \pm SD & & $3.2 \pm 0.8$ & $1.7 \pm 1.1^{*}$ & & $22 \pm 2.4$ & $20 \pm 2.5^{* *}$ \\
\hline
\end{tabular}

SRP: Spontaneous retrobulber pain, PEM: Pain on eye movement, ${ }^{*} \mathrm{p}<0.005,{ }^{* *} \mathrm{p}<0.05$ 
ment $(\mathrm{p}<0.005)$. The mean degree of proptosis, as measured with the Hertel exophthalmometer, also decreased slightly after the treatment $(22 \pm 2.4$ vs $20 \pm 2.5$ in total, $22.0 \pm 3.0$ vs $19.6 \pm 2.4$ for the right eyes and $22.1 \pm 2.0$ vs $20.3 \pm 2.6$ for the left eyes; $\mathrm{p}<0.05$ ). (Table 2). The NOSPECS score also showed improvement with the treatment $(3.2 \pm 0.7$ vs. $2.2 \pm 1.4 ; \mathrm{p}<0.02$ ).

When evaluated individually seven of the patients showed improvement in their activity scores with octreotide. Proptosis improved either slightly or significantly in 7 patients and three of these had normal proptosis values at the end of the study (case 4, 7, 9). Proptosis values did not change in one patient (case 8) and slightly decreased but still remained in high values in one patient (case 3). Two of the three patients (cases 6, 8 and 9) who were complaining of diplopia showed improvement at the end of the study (cases 6 and 9). Two patients (cases 6 and 8) showed no improvement in activity scores but in one of these patients proptosis decreased with OCT (case 6). No patient showed deterioration in the eye findings.

No difference in the therapeutic effects could be found between CS- unresponsive and CS- unsuitable patients $(p>0.05$ for both the activity score and proptosis value).

Four patients, who could be followed up after OCT treatment, remained favorable condition during the 20 month follow up. The other three responders did not come for their control visits after the third month since they wanted to be followed up by their local physician (Cases 1, 4, 9).

Three patients complained of abdominal pain and diarrhea and all had flatulence caused by the therapy. The adverse effects were eliminated in the second week of the treatment.

\section{Discussion}

These data confirm that OCT is effective in improving proptosis, diplopia and soft tissue involvement in patients with GO. The drug was beneficial in reducing both CAS and NOSPECS scores. The clinical activity score, one of the methods used to estimate disease activity, ameliorated in seven of nine, and the mean proptosis value decreased in seven and even normalized in three patients in a local population. Although it is hard to draw a conclusion from such a small number of patients, disease duration seemed to be a predictor of response to OCT, namely related to the disease activity, since five of the responders in the present study had a disease duration of less than 12 months.

In a number of recent studies OCT was found to be beneficial in GO [1-5, 9]. Özata et al. [1] found the drug to be effective in 8 of 10, Chang et al. [2] in 5 of 6 , Kung et al [4] in 8 of 8, Khoo et al. [5] in 6 of 8, and Krassas et al. [9] in all of 12 patients. Recently it was suggested that only octreotide orbital scanning (OctreoScan) positive patients benefit from this therapy $[3,9,10]$. On the other hand Durak et al., who used OCT in three OctreoScan positive patients, found no beneficial effect of the drug [6]. We did not perform OctreoScan in our patients, as it is expensive and time consuming. In addition a positive correlation between disease activity and OctreoScan - 111 uptake was reported by some investigators and it is well known that the clinical activity test is very cheap and easy to perform $[11,12]$.

The exact mechanism of OCT in GO has not yet been determined clearly. It was shown that OCT decreased urinary GAG [13]. Moreover, it was reported that somatostatin treatment could decrease the plasma concentration of IGF - $1[5,13,14]$ and could directly inhibit the release of lymphokines from lymphocytes $[3,9]$.

In conclusion, OCT seems to be safe and effective in the treatment of GO. The disadvantages of this treatment method are its expense and that because it has to be given three times as injections, patient selection becomes important. OCT can be used in patients who are unresponsive to CS therapy and/ or in whom CS is contraindicated, but the number of patients treated with octreotide was small, and further studies are needed to confirm the results.

\section{References}

1. Özata M, Bolu E, Şengül A, Tasar M, Beyhan, Z, Çorakçı A, and Gündoğan MA (1996) Effects of octreotide treatment of Graves ophthalmopathy and circulating sICAM - 1 levels. Thyroid 6: 283-288. 
2. Chang TC, Kao SCS, Huang KM (1992) Octreotide and Graves' ophthalmopathy and pretibial myxedema. Br Med J 304: 158.

3. Krassas GE, Kaltsas Th, Dumas A, Pontikides N, Tolis G (1997) Lanreotide in the treatment of patients with thyroid eye disease. Eur J Endocrinol 136: 416422.

4. Kung AWC, Michon J, Tai KS, Chan FL (1996) The effect of somatostatin versus corticosteroid in the treatment of Graves' ophthalmopathy. Thyroid 6: 381-384.

5. Khoo DHC, Tan YT, Fok, ACK, Tan CE (1995) Octreotide in the management of Grave's ophthalmopathy - changes in insulin - like growth factor 1 levels do not predict clinical response. $A m J$ Clin Res 4: 33-42.

6. Durak I, Durak H, Ergin M, Yürekli Y, Kaynak S (1995) Somatostatin receptors in the orbits. Clin Nuclear Med 20: 237-242.

7. Erdoğan G, Güllü S, Ilgın ŞŞ, Kamel AN, Başkal N, Uysal AR, Tonyukuk V, Çorapçıoğlu D (1998) Evaluation of the protrusion values of a healthy population with hertel exophthalmometer. J Ankara Med School 20: 135-137.

8. Wartofsky L (1992) Classification of eye changes of Graves' disease. Thyroid 2: 235-236.
9. Krassas GE, Dumas A, Pontikides N, Kaltsas Th (1995) Somatostatin receptor scintigraphy and octreotide treatment in patients with thyroid eye disease. Clin Endocrinol 42: 571-580.

10. Krassas GE (1998) Somatostatin analogues in the treatment of thyroid eye disease. Thyroid 8: 443-445.

11. Postema PTE, Krenning EP, Wijngaarde R, Kooy PPM, Oei HY, Van Den Bosch WA, Reubi JC, Wiersinga WM, Hooijkaas H, Van Der Loos T, Poublon RML, Lamberts SWJ, Henneman G (1994) [111 In-DTPA-D-Phe ${ }^{1}$ ] octreotide scintigraphy in thyroidal and orbital Graves' diseases. A parameter for disease activity. J Clin Endocrinol Metab 79: 1845-1851.

12. Kahaly G, Diaz M, Hahn K, Beyer J, Bockisch A (1995) Indium -111- Pentetreotide scintigraphy in Graves' ophthalmopathy. J Nucl Med 36: 550-554.

13. Chang TC, Ya WC, Chang CC (1992) Octreotide and urinary glycosaminoglycan in Graves' disease (letter). Br Med J 304: 1444.

14. Lamberts SWY, Oosterom R, Neufeld M, Del Pozo E (1985) The somatostatin analog SMS 201- 995 induces long - acting inhibition of growth hormone secretion without rebound hypersecretion in acromegalic patients. J Clin Endocrinol Metab 60: 1161-1165. 